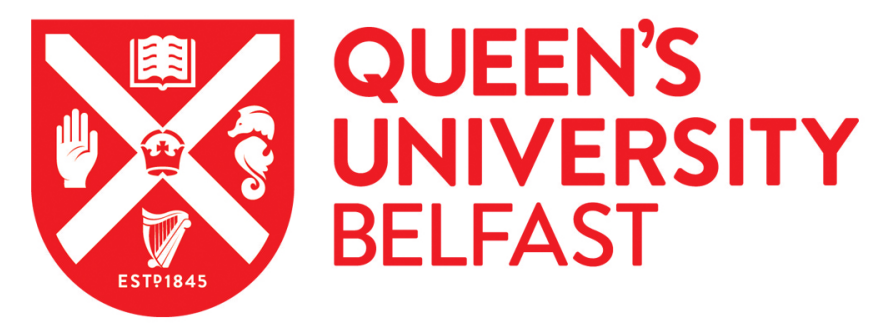

\title{
Editorial: International Political Sociology: Critical and Collective Adventures
}

Lisle, D., Squire, V., \& Doty, R. (2017). Editorial: International Political Sociology: Critical and Collective Adventures. International Political Sociology, 11(1), 1-4. https://doi.org/10.1093/ips/olw030

Published in:

International Political Sociology

Document Version:

Peer reviewed version

Queen's University Belfast - Research Portal:

Link to publication record in Queen's University Belfast Research Portal

Publisher rights

(c) 2017 The Author 2017. Published by Oxford University Press on behalf of the International Studies Association.

This work is made available online in accordance with the publisher's policies. Please refer to any applicable terms of use of the publisher.

\section{General rights}

Copyright for the publications made accessible via the Queen's University Belfast Research Portal is retained by the author(s) and / or other copyright owners and it is a condition of accessing these publications that users recognise and abide by the legal requirements associated with these rights.

Take down policy

The Research Portal is Queen's institutional repository that provides access to Queen's research output. Every effort has been made to ensure that content in the Research Portal does not infringe any person's rights, or applicable UK laws. If you discover content in the Research Portal that you believe breaches copyright or violates any law, please contact openaccess@qub.ac.uk. 


\section{International Political Sociology: Critical and Collective Adventures}

Over the last ten years, this journal has successfully undertaken an almost unprecedented task in the field of International Relations (IR): it has opened up a new terrain of research. By 'new' we do not mean that research combining the international, the political, and the sociological has never appeared in IR before; indeed, the journal has multiple origin points both within and outside the discipline. By 'new', instead, we mean that the journal has carved out a much-needed intellectual space whereby critical and transdisciplinary research into formations of the international can develop to new levels of sophistication. In a contemporary context where academic freedoms are increasingly under assault by governments, gatekeepers and managers, this achievement is no small thing. We want to begin by acknowledging the hard and often thankless efforts of the two previous editorial teams to create, nourish and protect this vital space of critical enquiry.

We see ourselves as fortunate to be taking on the journal in a very different context than the two previous editorial teams. Because of their hard work, we no longer have to face the task of repeatedly justifying why our work is legitimate in the context of IR. Those arguments have been made and comprehensively backed-up by a decade of excellent research. During that decade a powerful, diverse and energetic community has coalesced around a shared commitment to re-think the international from a critical and transdisciplinary perspective. Not only is there a 'thing' called IPS (which consistently questions its own origins, limits and blind spots), but there is also a large and growing community engaged in this collective endeavour. Sometimes we are in harmony, sometimes we are in dissonance, sometimes we are playing completely different songs and instruments - but within that polyphony is a shared commitment to problematizing entrenched accounts of the international and unearthing the plurality of global life-worlds. Thanks to the hard work of those before us, we embark on our time at IPS with optimism and hope: we have a recognized and legitimate - if shifting - ground from which to speak; we have the confidence to speak from that ground whilst simultaneously questioning its limits and tensions; and we have the good will and energy of a diverse community who are comfortable both inhabiting and critically exploring such a terrain.

We want to draw attention in particular to three important interventions that the journal has become renowned for over the past ten years. First, IPS has explicitly encouraged research that combines sophisticated theoretical argumentation with equally sophisticated empirical analysis. This is not a simple 'practice turn', but rather a much more transformative and challenging re-orientation that forces us to address difficult questions about how we actually 'do', express and value research. Second, IPS has opened up a dedicated space of enquiry between IR and Sociology that has rejuvenated important constitutive questions about methodology, epistemology and ontology. Thirdly, the journal has fostered important critical dispositions that constantly question the foundations upon which claims about the international are traditionally made, that demonstrate the way such claims can exclude, silence, efface and shut-down alternative global life-worlds, and that reveal how such alternative life-worlds always persist even in the bleakest situations. We want to consolidate these successes by encouraging research that troubles established ways of understanding the international - where it is found, when it emerges, and what kind of work it does in the world. We want to foster research that keeps the international / political / sociological in tension in order to reveal and contest formations of power, authority, exclusion and violence. For us, specifically, this means the following:

- Extending the global reach of the journal:

We want to critically analyse formations of the international with the widest bandwidth of voices possible. This means actively extending the global, geographical and cultural reach of the journal to more comprehensively reflect the multiple worlds we explore. 
While IPS attracts a great deal of excellent research from the dominant Anglo-American sphere (i.e. Europe, North America, Australia), we are politically, ethically and practically committed to encouraging submissions from voices outside of these regions. We have a linguistically diverse and geographically dispersed Communications Team to help us in this task, but we are also encouraging each of you as an IPS reader to bring the journal more explicitly into your global research networks through, for example, sharing our annual calls for research, engaging in transnational collaborations, and pursuing peer-topeer mentoring activities amongst your diverse communities.

- Broadening our transdisciplinary horizons:

Certainly we want to continue fostering the productive transdisciplinary conversations that our predecessors established between IR, Political Theory and Sociology. However, we are keen to enliven our interstitial starting place between the international-politicalsociological by encouraging further transdisciplinary conversations across disciplines such as Anthropology, Geography, Criminology, History, Political Economy, Literature and Creative Arts. Scholars in these areas are asking important questions about the formation and maintenance of the international, and we feel it is time to expand our transdisciplinary horizon accordingly. By reaching out more explicitly to our proximal disciplinary allies - and even to collaborators in science, technology, medicine and computing - we want to make the intellectual terrain of IPS more expansive and ambitious. In doing so, we hope to develop the feeling of productive discomfort that comes from openly acknowledging and actively encouraging the fractured, uncertain and porous character of all disciplines.

- Publishing relevant, responsive and challenging research:

We want submissions that do not shy away from the difficult work of explicitly addressing why a particular topic / question / puzzle matters to the terrain of the global, broadly conceived. We are interested in research that consistently prods at, re-imagines and thinks through the many linkages between the international, the political, the sociological and beyond, and does the difficult work of foregrounding and interrogating the 'so what' question. Given the state of the world we find ourselves in, we want submissions that respond carefully and critically to the many difficulties, horrors and forms of violence that shape our contemporary worlds, or that inform our historical and future trajectories. So many of the difficulties we see - catastrophic climate change, entrenched conflict, epic population displacements, the intensification of colonial asymmetries, the resurgence of fascisms, deepening political and social fragmentation, the silencing of multiple communities - demand careful consideration by an IPS community highly attentive to how global structures of power coalesce, disperse and recombine. However, we do not want work that confronts the horrors of our time by lapsing into cynicism, easy solutions or tired theoretical constructs - we would rather have challenging and difficult questions that continue to trouble us than easy solutions that comfort or placate. In short, we want work that confronts the plethora of global devastation with creative and hopeful combinations of the international, the political and the sociological.

- Encouraging pluralist approaches:

We welcome work that thinks through, works with and creates conversations between a variety of theoretical, conceptual, analytical and empirical approaches - in so far as these approaches do the work of showing how formations of the international are constituted, sustained and re-deployed. We also welcome work that finds new and innovative ways to explore how the international, political and sociological map onto (a) traditional units of global politics such as states, nations, communities and civilizations; and (b) familiar points of tension such as state/society; nature/culture;

domestic/international; modern/pre-modern. In particular, we welcome work that explores the multiple 'non-traditional' registers through which the international, the political and the 
sociological intersect, including (but certainly not limited to) the subatomic, affective, emotional, embodied, relational, material, semiotic, infrastructural, atmospheric and planetary. Empirically, we are especially keen to encourage submissions that use creative, emergent and innovative methods that challenge established academic conventions. In short, we want work that explicitly 'thinks' - not just easy 'applicationism', description, repetition or programmatic analysis. Over and above these stated horizons, we also welcome explorations of new areas, topics, approaches, problems and trajectories that IPS has not yet encountered or imagined. We want IPS to become a place where more experimental, speculative and questioning work can flourish. We feel this is an ambition worth protecting in an increasingly brutal academic system that too often reproduces convention, rewards safety and fails to take risks.

- Fostering a critical orientation:

One of the most enlivening cross-overs between IR and Sociology over the last decade has been a shared commitment to critical thinking and research. Indeed, one of IPS's core strengths has been the exploration and/or deployment of non-foundational theories and post-Positivist orientations that relentlessly question what is taken for granted when we speak about the international. Of course, we must also apply that incisive critical interrogation to our own endeavours and recognize the constitutive privilege of many of these positions. For this reason, we want to explicitly welcome submissions from allied critical traditions such as Postcolonialism, Decolonialism, Feminism, Queer Theory, Indigenous Politics and Environmentalism, which offer important and often uncomfortable insights about how even critical re-combinations of the international, the political and the sociological can coalesce into exclusionary formations. Thematically, we want to keep building on the excellent research IPS has published in core areas such as citizenship, borders, mobility, rights, surveillance and global security, but we also want to consider issues that are rendered invisible, or that operate in non-spectacular modes, slower rhythms or much longer narrative arcs (e.g. the persistence of colonial era inequalities; the commodification of everyday life; the aestheticization of violence; the neglected healthcare of entire populations; the normalization of poverty; the entrenchment of gender inequality; and the incremental rise of nationalist movements).

Our understanding of IPS as a journal, but also as a wider political project, is very much a collective endeavour. Indeed, IPS began with a shared dissatisfaction that the disciplinary boundaries and traditions of IR were limiting our capacity to analyse problems that were irrefutably international in scale, character and effect. We want to embed that collective ethos in all aspects of the journal, and to nourish it in the wider IPS community. For us, this starts with the collective nature of our practice. First, our editorial decisions are all informed by the wider IPS community through the process of peer review. We know this is not a perfect system; indeed, it is time-consuming, unacknowledged, and a form of silent labour that remains largely unrecognized by employers and by the profession. Moreover, we have all received unhelpful and perhaps even spiteful peer reviews of our work, and we know that this can be painful both personally and professionally. Still, as an editorial team, we want to be clear about our approach to the imperfect but workable collective peer review system that informs our decision making: (a) we absolutely appreciate the time and care that the IPS community puts into its peer review activities, and we encourage the 3-to1 rule (i.e. for every article you submit to any journal, we ask you to agree to three peer review requests); (b) we value and encourage peer reviews that are critically informed, thorough and decisive, but above all, that are intellectually generous, that are helpful to the author, and that engage with the intention of the work itself; and (c) we discourage peer reviews that are insensitive, self-aggrandizing, dismissive, petty and unsupportive of the author's intentions.

Second, while our editorial decisions are informed by the peer review process, we come to each final decision collectively through discussion, debate and negotiation. This can be timeconsuming (so please bear with us), but we feel very strongly that this is the best way to 
ensure that IPS publishes the highest quality research. This means research that thinks research that has already gone through the challenging self-editing process that is required to craft excellent arguments and make clear interventions. We know from creative writers that you cannot write clearly if you cannot think clearly - and we know that writing simply and clearly can be an extremely difficult endeavour. Self-editing is critical for first submissions, and is especially important when authors are asked to revise and resubmit their work: we ask that this process is given serious time, care and engagement.

We acknowledge that there may be members of the IPS community who will disagree with some of our future editorial decisions, or retreat from the more radical, transdisciplinary and speculative vision we have outlined for the journal's next stage. Indeed, we acknowledge that we may sometimes fail in our efforts to be more global, transdisciplinary, relevant, pluralist and critical over the next five years. But we collectively reject the paralyzing fear of failure and instead begin this adventure with a shared embrace of failure's capacity to energize and enliven - to make us think harder about what we do as a profession, to make us care more about how we engage with each other (however that other is figured), and to make our critical interventions more robust as we contest formations of the international that perpetuate violence, inflict damage and entrench exploitation. We are excited to embark on this endeavour together with you. 